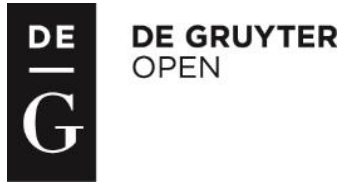

\author{
*George Volceanov \\ Facultatea de Litere \\ Universitatea "Spiru Haret" Bucureşti \\ Str. Ion Ghica, Nr.13, Sector 3 \\ Bucureşti, 030045, Romania \\ email: geovolceanov@yahoo.com
}

\title{
THE NEW ROMANIAN SHAKESPEARE SERIES ON THE MOVE: FROM PAGE TO STAGE AND SCREEN
}

\begin{abstract}
This article aims at presenting the impact that the New Romanian Shakespeare edition launched in 2010 by George Volceanov has had on the literati and theatres so far. It is, therefore, a stocktaking exercise and its main goal is to provide Shakespeare scholars with an initial data base for further investigation of theatrical productions which use the new translation as significant moments in the history of Shakespeare's reception in Romania and, on the other hand, to occasion some reflective remarks on the six years of the series now at its tenth volume and 26 plays plus the Sonnets.
\end{abstract}

Keywords: Shakespeare translation, page, stage, screen, performability, production.

Prequel to the New Shakespeare Edition

The idea of starting a New Romanian Shakespeare edition was preceded by the enlargement of the Shakespeare canon in Romania via the translation and publication of The Two Noble Kinsmen (by Polirom, as a bilingual edition, in 2002) and Edward III (2003), previously unknown to the general public, the theatre goers or theatre critics in Romania. For the latter title, Volceanov was rewarded by the jury of the Romanian Writers' Union with the Andrei Bantaş Foundation Translation Award. In the autumn of 2005, Ion Caramitru, the newly appointed then General Director of the National Theatre in Bucharest, announced that Edward III, a play recently attributed to Shakespeare (1985), will be brought to stage by theatre director Alexandru Tocilescu in the 2006-2007 season. Rehearsals began in late January 2007 and the Romanian premiere took place on January 26, 2008, featuring Caramitru himself in the leading role, alongside Șerban Ionescu (John of Valois), Crina Mureșan (the Countess of Salisbury), Daniel Badale (Prince Edward), Simona Bondoc (Queen Philippa), Eusebiu Ștefănescu (Warwick), Constantin Dinulescu / Alexandru Georgescu (Lord Audley), Marcelo Cobzariu (Robert d'Artois), George Paul Avram (Derby), Mircea Anca (Salisbury), Liviu Lucaci (Lorraine), Dani Popescu (Douglas / French sailor), Andrei Aradits / Axel Moustache (Lodowick),

\footnotetext{
* Dr George Volceanov is Associate Professor in English and Head of the Philology Department, Faculty of Letters, "Spiru Haret" University, Bucharest, Romania. He is a lexicographer, translator and editor, and has translated more than sixty books from English and Hungarian. He is the recipient of several translation awards. In recent years, he has written numerous articles and essays on Shakespeare's life and works, contributing, via critical texts and literary translations, to the enlargement of the Shakespeare canon in Romania. Since 2010 he is general editor of the New Romanian Shakespeare series, for which he has translated, or co-translated, thirteen plays so far. He is also author of several mono- and bilingual dictionaries of slang, being equally interested in Romanian, English and Hungarian slang.
} 
Dragoș Stemate (Charles, Duke of Normandy), Răzvan Hâncu (Prince Philip), Mihai Verbițchi (King David of Scotland), and many more, in a cast of over forty characters.

Alexandru Tocilescu's outlook on the play's message, the way in which the page-text was reshaped as, and metamorphosed into, stage-text, a step-by-step description of the production in performance and the mixed reviews it elicited, all these aspects are well documented in the very programme of the play and in several articles. ${ }^{1}$ Volceanov and Proudfoot's article on the Romanian Edward III provides an exhaustive list of reviews dated January and February 2008, and it will be cited in the 2016 Companion to the Oxford new edition of Shakespeare's Complete Works. As for Tocilescu's stunning production, suffice it to mention that the play was performed fifty-three times in the Grand Auditorium of the National Theatre in Bucharest, selling 40,000 tickets from 2008 to 2010. It also toured Greece (Demetra) and Bulgaria (Sofia). It was this production that brought together two of Leon D. Leviţchi's former students (Violeta Popa and George Volceanov), and it was hence that the idea of the re-translation of the whole canon originated. The box-office success of this production and the accolades the translation received at the time, from both the director and the leading actor, set into motion the whole later project.

\section{Prologue: The Page}

The strategy and the "poetics" of the New Romanian Shakespeare edition have been the topic of several articles written in the past few years and they refer to the use of modern vocabulary, that is accessible to present-day readers and theatre-goers; the recuperation of previously (self-)censored political, social and religious terms; the de-bowdlerization of Shakespeare's text; the creation of performance-oriented Romanian versions, insofar as, in his time, Shakespeare did actually write for the stage, not for the page; and the need to observe Schlegel and Tieck's principle of stringency, which means due respect paid to the original forms of dialogue, whether prose, blank verse or rhyming couplets in iambic pentameters and so on. ${ }^{2}$

\section{0-2016: A Survey}

The first four volumes of the new edition were published by Paralela 45 Publishing House in 2010 and 2011, volume 5 was jointly published by Tracus Arte and The Romanian Cultural Institute in 2012, and volumes 6 to 10 were published by Tracus Arte with funding from AFCN, between 2013 and 2015.

The names of the participants - to date - in the translation project include: Violeta Popa (a dramaturge working with The National Theatre in Bucharest), Horia Gârbea and Lucia Verona (well-

\footnotetext{
1 See Tocilescu, A. 2008. "Mi-am respectat jurământul." Eduard al III-lea, Caiet program. Teatrul Naţional Bucureşti, Stagiunea 2007-2008. 23; Volceanov, G. “Ah, but it is mine oath: On Alexandru Tocilescu's Rereading of Edward III." In Annals of "Dunărea de Jos" University. Fascicle XIII. Language and Literature. Issue 29, 2010. 45-54; Volceanov, G. 2010. "From Printed Text to Stage Version: Reshaping Shakespeare for Performance - Edward III at the National Theatre in Bucharest." Multicultural Shakespeare: Translation, Appropriation and Performance", vols. 6 (21) / 7 (22). 51-70; "Cum se naşte un spectacol - Şcoala culiselor." Eduard al III-lea, Caiet program, TNB, Stagiunea 2007-2008, 37-39; Volceanov, G. and Proudfoot, R. 2011. "King Edward III Conquers Romania." In quarto.u-paris10.fr/index.php?id=58.

${ }^{2}$ For more details, see Volceanov, G. 2010. "Fifty Ways to Betray the Bard." In Nicolaescu, M. and Corneanu, S., (eds.), (In)Hospitable Translations: Fidelities, Betrayals, Rewritings. Bucharest: EUB. 33-48; Volceanov, G. 2011. "Modern vs. Archaic, Page- and Stage-oriented Text: On Two Romanian Versions of Shakespeare's King John." Translation Studies: Retrospective and Prospective Views, Year IV, no. 12. 99-117; Volceanov, G. 2011. "Censored (?) Shakespeare in Communist Romania." In Analele Universităţii Alexandru Ioan Cuza din Iaşi. Limbi şi literaturi străine. Supliment la Tomul XIV, In Honorem Odette Blumenfeld. 85-102; Volceanov, G. 2012. "Translating and Editing Shakespeare Today." In Ruxandra Vasilescu et al. (eds.), Challenges in Translation: Space, Culture and Linguistic Identity. New York: Addleton Academic Publishers. 30-42; Volceanov, G. 2012. "Shakespeare în mileniul trei." Lettre Internationale No. 80-81, iarnă-primăvară, 85-87; Volceanov, G. 2014. "Măsură pentru măsură într-o nouă traducere.”România literară no. 19. 21; "Despre încâlcitele ițe ale canonului shakespearian.” România literară No. 12. 24-25.
} 
known and successful playwrights), Ioana Diaconescu (poet), Adriana Volceanov and George Volceanov (literary translators). The latter also became the project's editor in chief. The introductions to the new translations have been commissioned to Shakespeare scholars and academics working at several universities in Romania and abroad: Pia Brînzeu, Odette Blumenfeld, Nicoleta Cinpoeș, Gabriela Colipcă, Codrin Liviu Cuțitaru, Lucian Ghita, Monica Matei-Chesnoiu, Iulia Milică, Dana Monah, Mădălina Nicolaescu, Dana Percec, Veronica Popescu, Emil Sîrbulescu, the late Eugenia Gavriliu and George Volceanov. The one notable exception to date is the introduction written by one of the translators, namely Horia Gârbea, to Henry VI, Part Three.

The list of works published so far consists of the following titles ${ }^{3}$, in chronological sequence: The Sonnets (VP), The Tempest (GV) - in Volume 1 (2010); Hamlet (Q1, Q2 and F versions - VP \& GV) - in Volume 2 (2010); Twelfth Night (VP \& GV), The Two Noble Kinsmen (GV), The Merry Wives of Windsor (AV \& GV) - in Volume 3 (2010); The Taming of the Shrew (VP), King John (GV), A Midsummer Night's Dream (HG) - in Volume 4 (2011) The Merchant of Venice (HG), Troilus and Cressida (LV), Timon of Athens (GV) - in Volume 5 (2012); As You Like It (VP), The Two Gentlemen of Verona (LV), 1 Henry VI (ID) - in Volume 6 (2013); Antony and Cleopatra (ID \& HG), 2 Henry VI (LV), 3 Henry VI (HG) - in Volume 7 (2013); Richard III (HG), Measure for Measure (GV), The Winter's Tale (VP) - in Volume 8 (2014); Edward III (GV), Much Ado about Nothing (LV), Macbeth (HG) - in Volume 9 (2014); The Comedy of Errors (GV), Julius Caesar (LV \& HG), Othello (LV) - in Volume 10 (2015). The table of contents of the forthcoming Volumes 11 and 12, to be issued in October 2016 includes Richard II (GV), 1 Henry IV (GV) and 2 Henry IV (LV), and Henry V (HG), Henry VIII (LV \& HG), and Sir Thomas More (GV, HG, LV \& VP), respectively.

The Impact of the New Shakespeare Edition on Literary Circles

The new edition launched in 2010 had an immediate impact as a "page" project. The first two volumes were shortlisted alongside exclusively originals works by renowned contemporary writers such as Ana Blandiana, Gabriela Adameşteanu and Horia Roman Patapievici, for the most prestigious Romanian literary award, the Book of the Year, awarded by the Romanian Writers' Union weekly magazine România literară in 2010 and it received the award. Volume 1 was shortlisted for the Romanian Writers' Union Translation Award and the "Andrei Bantaş" Foundation Translation Award for the same year. A year later, Violeta Popa, George Volceanov and Horia Gârbea received the "Andrei Bantaş" Foundation Translation Award conferred by the jury of the Romanian Writers' Union for Volume 4. In 2012, the weekly magazine Observator cultural awarded the editor in chief (GV), alongside Sorin Mărculescu, the (re-)translator of Cervantes' Complete Works, an Honorary Diploma for Lifetime Achievement. The undisputed importance of the new edition was acknowledged once again in the autumn of 2014, when România literară included volumes 8 and 9 among the books nominated to the Book of the Year. A few months later, the same volumes (including translations by GV, HG, LV and VP) won the Romanian Writers' Union Translation Award for 2014. Shakespeare450 and Shakespeare - 400, the worldwide anniversary and commemoration of the Bard, respectively - in 2014 and 2016 - have constantly kept the new Romanian edition in the spotlight. The editor in chief was invited by the cultural media to write about Shakespeare (as well as the new edition) in several literary magazines, from Lettre Internationale, to România literară and Dilema veche ${ }^{4}$; Sever Voinescu, the editor-in-chief of Dilema veche, praised Volceanov's article, his new translations and their underlying strategy ${ }^{5}$. The edition became the topic of several interviews in printed and on-line journals, as well as on the radio (Radio România Culturală has hosted several half-hour shows with

\footnotetext{
3 The translators' names will be provided in brackets, using the acronyms VP (for Violeta Popa), HG (for Horia Gârbea), LV (for Lucia Verona), ID (for Ioana Diaconescu), AV (for Adriana Volceanov) and GV (for George Volceanov).

4 Volceanov, G. "Un altfel de Shakespeare - unul fără perdea." Dilema veche. 635, 21-27 April 2016. III; "Marlowe şi Shakespeare, Shakespeare şi Marlowe." Lettre Internationale, 97/2016. 74-78; "Shakespeare la el acasă, Shakespeare în lume şi în România." România literară, 18-19 / 2016. 28-29; "Shakespeare - 400." Revista de Traduceri Literare, 6/2016 (online).

${ }^{5}$ Voinescu, S.“Shakespeare tradus, dar netrădat.” Evenimentul zilei, 10 May 2016.
} 
Volceanov, Gârbea and Verona) and television (the 2016 documentary series Shakespearia, produced by TVR2 in conjunction with the British Council, contains footage with commentaries by Volceanov and Gârbea on the significance of some Shakespeare plays, such as A Midsummer Night's Dream, The Merchant of Venice, Hamlet, King Lear, Twelfth Night, Romeo and Juliet, as well as of the new Romanian edition). ${ }^{6}$ Fragments from the translators' work in progress and essays on aspects of translation have appeared in several literary magazines. ${ }^{7}$ Earlier, in 2013 and 2014, Volceanov produced a TV series on TVH, "Univers Shakespeare", which also contributed to the promotion of the new edition.

The Stage: The Impact of the New Shakespeare Edition on Theatre Practice

The transfer of the new translations from the page to the stage stagnated for four long years after the Romanian premiere of Edward III. In February 2012, Silviu Purcărete combined the new translation of The Tempest by Volceanov with Leon Levițchi's canonical version (from 1958), Ioana Ieronim's more recent rendering (2007) and David Esrig's stage-text of the late 1960s to produce his own heavily abridged script-text for his adaptation titled - fittingly given the script negotiation exercise A Tempest, directed for the Marin Sorescu National Theatre, Craiova, Romania. Performed during the eighth edition of the International Shakespeare Festival, Craiova, 2012, this particular production was covered by a large number of reviews ${ }^{8}$ and was invited to participate in several theatre festivals both in Romania and abroad mostly thanks to Purcărete's enduring international reputation acquired back in the 1990s rather than the production's success. During the same edition of the Festival, at the festival director Emil Boroghină's initiative, the new translations began to be used as surtitles for the productions brought by the foreign companies invited. Most notably, Violeta Popa's translation of the Sonnets was projected during Robert Wilson's memorable dramatization of Shakespeare's lyrical poetry. Later on, in 2014, Horia Gârbea's translation of Richard III was used for the surtitles of the two invited productions of the play: one from the National Theatre of Beijing, China (directed by Wang Xiaoyin) and the other from AM Production in collaboration with the National Arts Festival and Market Theatre in Cape Town, South Africa (directed by Fred Abrahamse). Gârbea's translation of A Midsummer Night's Dream accompanied the performance of the play by Propeller Theatre Company (UK), while Popa's and Volceanov's translations bridged the linguistic gap between the Romanian spectators and the actors from the Budapest National Theatre in As You Like It (directed by

\footnotetext{
${ }^{6}$ Andronescu, M. “George Volceanov: Traducerea a devenit un drog, un modus vivendi." Ziarul Metropolis, 12 February 2016; Tronaru, D. "Mai e Shakespeare contemporanul nostru? INTERVIU cu traducătorul George Volceanov: Shakespeare a fost un oportunist, şi cu regina şi cu Essex.” Adevarul, 22 April 2016 (http://adevarul.ro/cultura/carti); "George Volceanov: Traducerea literară reprezintă întotdeauna un proces infinit (George Volceanov: About Shakespeare).” Movie by Simion Buia. Ziarul Metropolis, 25 April 2016; G. Volceanov and H. Gârbea, guests of Vorba de cultură, a show hosted by Ema Stere and Attila Vizauer on Radio România Culturală on April 11 and April 15, 2016, respectively; G. Volceanov, guest of Dilema veche la timpul prezent, a radio show hosted by Adela Greceanu and Matei Martin on Radio România Culturală on April 21, 2016; "Horia Gârbea: Lecţia supremă a lui Shakespeare ne spune că magia este memoria," interview by Lucian Vasilescu, Mediafax, April 23, 2016; L. Verona, guest of Răzvan Dolea and Valentin Protopopescu's show Texte și pretexte on Radio Romania Cultural, on April 23, 2016; G. Volceanov, again, guest of Vorba de cultură from May 23 to May 27, 2016. In June, Trinitas TV channel will broadcast a one-hour show, dedicated to the new Shakespeare edition, hosted by Marina Baconschi: invited guests are G. Volceanov and Mihaela Anghelescu-Irimia.

${ }^{7}$ Fragments of work in progress published in 2016: Volceanov, G. "Atelierul traducătorului: Retraducând Henric al IV-lea (Partea întâi) de Shakespeare." Revista de Traduceri Literare, 4/2016 (online); Gârbea, H. and Volceanov, G. "Coriolanus (fragmente)." Luceafărul de dimineaţă, 4/2016. 24; Gârbea, H. "Viaţa regelui Henric al V-lea." România literară, 18-19 / 2016. 34.

${ }^{8}$ See, for instance, the reviews written by Monica Andronescu (Yorick, February 20, 2012), Adrian Mihalache (SpectActor, 1/2012) and Oltița Cântec (SpectActor, 2/2012), Marcin Miętus (Balkanistyka.org, Poland), Szymon Spichalski (Teatr dla Was, Poland), Katarzyna Wysocka (PortKultury.pl., Poland). Courtesy of Nicolae Coande, dramaturge and PR at the "Marin Sorescu" National Theatre, Craiova.
} 
the Silviu Purcărete), the OKT Company from Vilnius in Miranda (directed by Oskaras Korsunovas) and the Vakhtangov Theatre from Moscow in Measure for Measure (directed by Yuri Butusov).

In 2016 Popa and Volceanov's 2010 translation of Hamlet was used for the surtitles of performances by the South-African Abrahamse and Meyers, the British Flute Theatre and Shakespeare at the Tobacco Company. The audience enjoyed the new Romanian translation and according to Mona Dragomirescu, who was in charge with the projection of the surtitles, the translation of Hamlet's speech "Do you think I meant country matters?" ("Credeai că mă gândesc la vreo păsărică?" in III. 2) made audiences roar with laughter on every single occasion. ${ }^{9}$ Macbeth (HG), Richard III (HG) and The Winter's Tale (VP) were also projected during the 2016 edition.

Outside the success of the new translations in the context of the International Shakespeare Festival, Craiova, Romania, the reality check painted a different picture. 2013 was a year of unfulfilled, with no Shakespeare production bent on using the new translations. Things changed for the better in 2014, when the Tony Bulandra Theatre in Târgoviște mounted two Shakespeare plays in rapid succession. Two foreign directors were invited to stage Popa and Volceanov's versions of Hamlet and Twelfth Night, respectively: Kemal Bashar (Turkey) and Di Travis (British). Hamlet had its opening night on September 1, 2014 and was followed swiftly by Twelfth Night, which opened on October 4, 2014.

Despite the fact that Bashar's production received great hype from the local media, it remained just a local phenomenon. Its whole concept was to have a site-specific production performed outdoors, namely on the ruins of the mediaeval Princely Court in Târgoviște. As a result, it could not tour and, with a local population of 100,000 inhabitants, it faded away after a handful of performances. No record of this production exists on Google, and no reviews have appeared in professional theatre journals, such as Teatrul azi or Yorick. The Romanian translation was heavily cut and the verse was rendered as prose to facilitate the actors' interpretation. The only recognizable, unaltered passages of the translation were the play-within-the-play and Ophelia's songs, which did preserve the rhyming couplets of Popa and Volceanov's translation. Notwithstanding Di Travis' impressive record as director, Twelfth Night - like Bashar's Hamlet - failed to capture the attention of a wider audience; in this case, too, no review of the production is available, whether online or in print.

As time drew closer to the worldwide celebration of Shakespeare - 400, more and more directors and theatres focused their efforts on staging new Shakespeare productions. Victor Ioan Frunză directed three Shakespeare plays within a few months in 2015. He rejected Gârbea's new translation of A Midsummer Night's Dream, using instead his own (?) "stage version", and requested a new version of Romeo in Juliet, but this had not yet been re-translated at the time, he commissioned the London-based freelance writer Adrian N. George to produce a new script, which he then adapted. Frunză's third production, of Twelfth Night, opened at Metropolis Theatre, Bucharest, on September 27, 2015. It had a better fate than his earlier productions. At the most recent check (16 May 2016), the production remains a sell-out, with two performances a week and with hundreds of teenagers going to see it more than once. Its success may be due to the fact that the cast contains a core group of actors with whom Frunză has been working for several years: George Costin (Malvolio), Sorin Miron (Sir Andrew Aguecheek), Nicoleta Hâncu (Viola), Adrian Nicolae (Sir Toby Belch), Andrei Huţuleac (Feste) and Alexandru Pavel (Orsino). The company was awarded the Prize for Theatre for their outstanding interpretation of two Shakespeare plays, Romeo and Juliet and Twelfth Night, at the first edition of "Matei Brâncoveanu" Awards Gala in December 2015, with the newly created awards aiming to reward specifically young talent - whether artists or scholars.

The new Romanian translation of Twelfth Night employed by Frunză did not go unnoticed. Val Vâlcu remarked that "Shakespeare's verse, translated by Violeta Popa and George Volceanov, alternates with passages 'spoken' in present-day Romanian (phrases, interjections, jargon). I think that had the author lived in Romania now, he would have written in this very way." (13 October 2015). Monica Andronescu lavishly praised the new translation, which "in this new production retrieves a language that is much closer to Shakespeare's, a language that was excessively made to sound like poetry, deprived of the sap, the authenticity that is so necessary especially in the comic scenes, in which vulgarity is particularly charming and meaningful." (1 December 2015).

\footnotetext{
${ }^{9}$ Mona Dragomirescu, personal communication, 23 April 2016.
} 
2015 was definitely the breakthrough year of the New Shakespeare edition. Three more productions relied on the new translations of Shakespeare's work. Silviu Purcărete's much acclaimed Julius Caesar for The Hungarian State Theatre in Cluj, which opened on October 6, 2015, employed Verona and Gârbea's translation not just as surtitles but also as check text during the Hungarian actors' rehearsals conducted by the Romanian director. This production instantly captured the drama critics' attention, being widely reviewed. ${ }^{10}$ All reviewers praised the director's original vision. One of the "original" issues was the performance of actor Bogdan Zsolt's (Caesar) dog turned symbol of the Roman wolf, dragged on stage "dead" after the murder of his master. From a translator's (and editorin-chief's) viewpoint, I was happy to notice that the Hungarian company, the Romanian and the Hungarian reviewers, embraced the spelling proposed by the new translation: Iulius Caesar (instead of Iuliu Cezar).

In 2015, Di Travis returned to Târgoviște for another Shakespeare production which met the same fate: it went unnoticed by theatre critics. Her Richard III opened on October 3, 2015. In an interview published on 2 October 2015 in the local on-line journal Oficial Media, the director boasted: "I used five different versions to make up a text of mine. I worked for three months with the respective translations before I made my own compilation." It is quite questionable what an English director can make out of texts in a language she does not understand, but such things happen more often than not in theatres all over the world. One of the five versions was Horia Gârbea's, who filed a complaint to the Police in Târgoviște against the theatre for not being notified about the opening night and not being paid due royalties. Lucia Verona shared Horia Gârbea's unpleasant experience of learning from the internet, in January 2016, that her translation of Much Ado About Nothing had been used by Alexander Hausvater for his production premiered at the Ioan Slavici State Theatre, Arad, on 14 November 14. Like her, I could find no review of this production so far.

Faring better in the hands of director Cristian Ioan, The Merchant of Venice (in Gârbea's new version) opened at the Elvira Godeanu Theatre in Târgu Jiu on March 5, 2016, featuring the theatre manager Marian Negrescu as Shylock. According to local reviewer George Drăghescu, "with his translation, Horia Gârbea has proved that a true writer can also be an exceptional translator." The same reviewer cited veteran reviewer Ion Cocora's opinion about "a very special show in terms of atmosphere and vision, correlated with Horia Gârbea's translation, which is perceptive and modern. The actors' participation and the director's conception have elevated the story beyond the simple facts it tells, generalized it and created a subtext."

The latest example to date of the New Edition's fortunes on the stage is Julius Caesar, which opened at the "Marin Sorescu" National Theatre, Craiova, on 17 April 2016. Directed by ex-Walt Disney Studios president Peter Schneider, the Craiova National Theatre company led by the talents of Claudiu Bleonţ (Brutus), Adrian Andone (Caesar), George Albert Costea (Casca) and Gina Călinoiu (Portia) used a heavily cut and compressed version of Gârbea and Verona's translation, which had been commissioned as early as September 2014. Mircea Morariu offers an excellent first-hand review on April 19, 2016 in Adevărul, in which he deplores the director's excessive focus on visual images. I myself expressed a similar opinion in an article dedicated to the Shakespeare Symposium organized by the National Museum of Romanian literature in conjunction with the Romanian Cultural Institute and the Philology Section of the Romanian Academy in Bucharest, 12-14 April 2016, and to the Shakespeare Festival in Craiova: Schneider's production "is the triumph of multimedia means over interpretation, over the actors reduced to simple pawns on the grand chessboard of history."11

${ }^{10}$ Here is an exhaustive list of reviews, both in Romanian and Hungarian, to date, courtesy of actress Csilla Albert, who played the Soothsayer: Adrian Țion, "Câinele are rolul său." Agenda LiterNet, 15 December 2015; Cătălin Bogdan, "În ritm de sumo" Revista 22, 3 November 2015; Radu Constantinescu, "Shakespeare, Caesar şi Purcărete.” Ziarul financiar, 5 November 2015; Gergely Borbala, “A joszandeku torekvesek altal elinditott pusztulas (Destruction stemming from good intentions)." Transindex 12 November 2015; Janko Szep Yvette, "Caesar, a jos es az ubermarionette (Caesar, the soothsayer and the uberpuppet)." Jatekter Winter 2015, 9-13; Mircea Morariu, "O lume în deconstrucţie." Adevărul, 4 January 2016; Lovassy Cseh Tamas, "Es te, fiam? (Et tu, Brute?)." Igen, tessek!, 17 November 2015; Nano Csaba, "A zsarnok halala Kolozsvaron (The tyrant's death in Cluj)." Erdelyi naplo, 17 October 2015; Pacsika Emilia, "Philippi es annak szelleme (Philippi and its spirit)." Erdelyi naplo, 9 January 2016; Sakolczay Lajos, "Kortarsunk Shakespeare es Roma (Shakespeare, our contemporary, and Rome).” Magyar idok, 22 December 2015.

${ }^{11}$ Volceanov, G. "Shakespeare - 400, Conferinţe, simpozioane, festivaluri." Opinia naţională, 3 May 2016. 1-5. 
By a happy coincidence, the tenth edition of the International Shakespeare Festival, Craiova, coincided with the launch of the tenth volume of the New Romanian Shakespeare edition and with the opening of the tenth production that used a new translation published between 2010 and 2016. The New Romanian Shakespeare edition continues to make history as I'm writing this article and records a new premiere: in early May, during the annual European Film Festival held in Bucharest, a selection of films - Laurence Olivier's Hamlet (1948), Kenneth Branagh's Much Ado about Nothing (1993) and Derek Jarman's The Angelic Conversation (1985) - meant to celebrate Shakespeare, used for the first time the new translations by Violeta Popa, George Volceanov and Lucia Verona as subtitles projected in movie theatres.

Forthcoming Productions and Spin-offs...

2016, the biggest Shakespeare anniversary year for another half of a century, is far from over. Even as I am writing this article, a few projects are waiting to be completed in the coming weeks and months. The "Lucia Sturza Bulandra" Theatre will celebrate Shakespeare with two new productions this year. The Czech director Michal Docekal will direct Macbeth (in Horia Gârbea's translation), while Romanian director Ducu Darie will use the new Romanian translation of Coriolanus (by Gârbea and Volceanov) for his next production. Director Doru Mareș has been trying for a while to include Richard III (in Gârbea's translation) in the repertoire of the "Bacovia" Municipal Theatre, Bacău. A possible by-product of the New Shakespeare series might be staging Back to Elsinore - A Danish Play, a rewriting of Hamlet by Hungarian director and dramatist Kiss Csaba, translated into Romanian by Susana Vlaicu and George Volceanov. And yet another spin-off of may be Romanian directors' increasing interest in Jacobean drama: Radu Afrim and Ducu Darie have been thinking for years on about mounting The Duchess of Malfi (translated by Volceanov and published back in 2004 by Editura Institutul European in Iaşi).

Post scriptum or A Survey of Missed Opportunities and Failed Projects

Every story of success probably has its dark, less(er) known counterpart. The way to success is often paved with failures and missed opportunities. Had things happened differently, the New Shakespeare edition could have boasted fifteen or twenty productions based on its texts instead of just ten.

As early as 2007, Visky András, dramaturge for the Hungarian State Theatre, Cluj, got in contact and asked me to provide a new version of King Lear for Tompa Gábor production for the Cluj National Theatre. As I was otherwise engaged, writing a series of lectures in English poetry, I had to turn down the proposal and warmly recommend, instead, Dragoş Protopopescu's earlier translation dating back to the beginning of the twentieth century. As a result, Marian Râlea created a memorable Lear in the ensuing production.

Back in 2008, director Szabó K. István, then working with Teatrul Tineretului in Piatra Neamţ, commissioned me to translate The Tempest for a production starring Constantin Cojocaru as Prospero. Just a few weeks into the indoor rehearsals (following the outdoor shooting of Ferdinand and Miranda's wedding in an orchard), the project was abruptly brought to a halt by the lack of funds as the latest economic crisis put the theatre off its stride. A year later the same theatre premiered the first Romanian-language production of the Hungarian playwright drama The Soldiers in my translation, to compensate for the royalties it paid me in advance.

In 2013 Alexandru Mâzgăreanu mounted Twelfth Night at the "Regina Maria" State Theatre, Oradea. His original intention was to use a text adapted from translations by Mihnea Gheorghiu (1959) and Popa \& Volceanov (2010); when Violeta Popa rejected the idea, the director resorted to using only Gheorghiu's version.

Bucharest National Theatre managing director Ion Caramitru praised my new translation of The Tempest on several public and private occasions; yet, when Alexander Morfov was invited in 2014 to direct the play at the Bucharest National, the company used Nina Cassian's earlier version, allegedly on economic grounds - the ailing poetess (who sadly died a few days after the opening night) demanded no royalties.

In the summer of 2015, young freelance actor and director Orlando Petriceanu started rehearsals with Popa and Volceanov's Hamlet at the Act Theatre in Bucharest, with Pavel Bârsan, an 
excellent comedian, starring as the Danish Prince. Petriceanu's directing strategies, his sociological and meta-aesthetic theories generated frictions among the actors and the troupe was soon disbanded.

In early October 2015, I was contacted by the "Vasile Alecsandri" National Theatre in Iaşi regarding my translation of The Tempest. German director Christina Paulhoffer was expected to come and mount the play for the Shakespeare Year. It turned out that, like Peter Schneider in Craiova, Paulhoffer asked for complete control over the project team, insisting on bringing in a whole team of light designers, costume makers, etc. The theatre could not cope with all of the demands and was forced to bring the project to a halt.

Such details are part and parcel of a parallel, invisible cultural history and they ought to be retrieved. After all, culture and the arts are not a string of successful events but a mixture of failure and success. And failure often reminds us that history "could have been different, if only...".

\section{Works Cited:}

Andronescu, M. "Narcisism şi cinism." Yorick, 1 December 2015.

Drăghescu, G. "Cronica dramatică." Gorjeanul, 23 March 2016.

Iordache, C. and Grigore, O. M. "Di Trevis- Richard al treilea- Teatrul Tony Bulandra Târgoviște."

OficialMedia. 2 October 2015. http://oficialmedia.com/di-trevis-richard-al-treilea-teatrul-tonybulandra-targoviste/. Retrieved on 10 June 2016.

Vâlcu, V. "Montagne russes în interiorul unui teatru: lovitură pe scena bucureșteană." DCNews.ro, 13 October 2015.

Volceanov, G. "Shakespeare - 400, Conferințe, simpozioane, festivaluri." Opinia naţională, 3 May 2016. 1-5. 